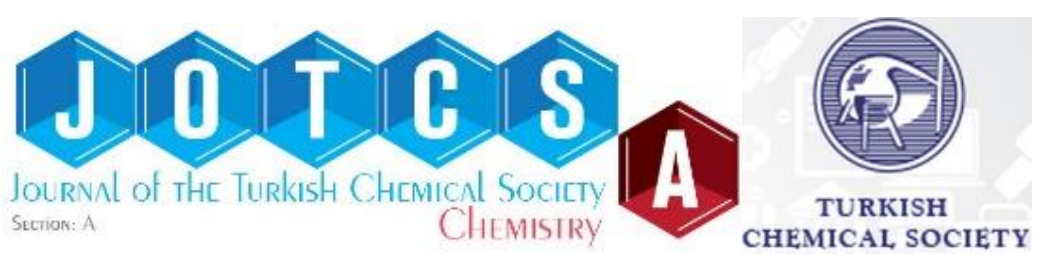

\title{
Palladium(II) Complexes of Monodentate Phosphine Ligands and Their Application as Catalyst in Suzuki-Miyaura C-C Coupling Reaction at Room Temperature
}

\author{
Mustafa Kemal Yılmaza, $\triangle$, Simay İnceb $D$ \\ aMersin University, Faculty of Arts and Sciences, Department of Chemistry, 33343 Mersin, Turkey. \\ bOsmaniye Korkut Ata University, Faculty of Arts and Sciences, Department of Chemistry, \\ 80000 Osmaniye, Turkey.
}

\begin{abstract}
A series of palladium(II) complexes from monodentate phosphine ligands (1a-4a) were successfully prepared and characterized with ${ }^{1} \mathrm{H},{ }^{31} \mathrm{P},{ }^{13} \mathrm{C} N \mathrm{NMR}$, and HRMS techniques. These pre-catalysts were applied for the Suzuki-Miyaura C-C coupling reaction of phenylboronic acid with bromobenzene and the influence of the base and solvent on the performance of the pre-catalysts was investigated. Sterically hindered and electronically deactivated aryl bromides as well as activated ones gave the corresponding coupling products in good to excellent yields at room temperature.
\end{abstract}

Keywords: Palladium, catalyst, phosphine, Suzuki-Miyaura C-C coupling.

Submitted: June 20, 2018. Accepted: July 17, 2018.

Cite this: Yılmaz M, İnce S. Palladium(II) Complexes of Monodentate Phosphine Ligands and Their Application as Catalyst in Suzuki-Miyaura C-C Coupling Reaction at Room Temperature. JOTCSA. 2018;5(2):895-902.

DOI: http://dx.doi.org/10.18596/jotcsa.435122.

*Corresponding author. E-mail: mkyilmaz@mersin.edu.tr. Tel.: +90 32436100 01; fax: 90324361 0073. 


\section{INTRODUCTION}

Suzuki-Miyaura carbon-carbon (SM) coupling reactions generally catalyzed by palladium complexes have been most widely studied for the construction of new carbon-carbon bonds, since they allow the formation of highly complex molecules from relatively simple precursor (1-3). In the SM coupling reaction carbon-carbon bond formation takes place between phenylboronic acid and aryl or vinyl halides. In many cases, the reaction is homogeneously catalyzed by $\mathrm{Pd}(\mathrm{II})$ or $\mathrm{Pd}(0)$ complexes which were generally formed with phosphine, $\mathrm{N}$-heterocyclic carbene (NHC) or salen type ligands, in good conversions and high yields. Especially, monodentate or bidentate phosphine ligands have been successfully applied for palladium-catalyzed C-C coupling reactions such as SM coupling because of their high reactivity, high turnover numbers and milder reaction conditions (4). Although extremely high catalytic activities can sometimes be achieved by using phosphine-free palladium catalysts such as $\mathrm{Pd}(\mathrm{OAc})_{2},\left[\left\{\left(\eta^{3}-\mathrm{C}_{3} \mathrm{H}_{5}\right) \mathrm{PdCl}\right\}_{2}\right]$, and $\left[\mathrm{Pd}_{2}(\mathrm{dba})_{3}\right]$, in some cases the formation of inactive palladium black during the catalytic cycle reveals the necessity of increasing the stability of the palladium center. So, sterically hindered tertiary phosphine ligands are generally used which has often circumvented catalyst deactivation by inhibiting the formation of palladium black $(5,6)$.

So far, many types of monodentate phosphine ligands and their metal catalysts have been prepared and applied for various catalytic transformations such as hydrogenation, hydroformylation or several carbon-carbon coupling reactions etc., (7-9) but triphenylphosphine-based palladium(II) precatalysts were not examined for SM coupling reactions. Here we focused on the synthesis and characterization a series of $\mathrm{Pd}$ (II) complexes which have monodentate tertiary phosphine ligands and optimization studies of these precatalysts for SM coupling reactions. These precatalysts were also applied for SM coupling reactions using a wide range of substituted substrates, bearing electron releasing or withdrawing groups at different positions.

\section{MATERIALS AND METHODS}

\section{General}

All of the reagents were purchased from commercial sources (Aldrich or ABCR) and used as received, unless otherwise indicated. The solvents were dried, deoxygenated, and purified according to standard methods in the literature (10). 2-(Diphenylphosphino)benzaldehyde (1), 2-(bis(3,5-dimethylphenyl)phosphino)

benzaldehyde (2), 2-(bis(3,5bis(trifluoromethyl)phenyl)phosphino)benzaldeh yde (3) and 2-(bis(4tolyl)phosphino)benzaldehyde (4) and their Pd(II) complexes were prepared according to the published procedures (11-14). Pd(II) complexes were characterized by NMR analyses on a Bruker Ultrashield Plus Biospin Avance III 400 spectrometer NaNoBay FT-NMR operating at 400.2 MHz ( $\left.{ }^{1} \mathrm{H} N M R\right), 162.0 \mathrm{MHz}\left({ }^{31} \mathrm{P}\left\{{ }^{1} \mathrm{H}\right\} \mathrm{NMR}\right)$ and $100.2 \mathrm{MHz}\left({ }^{13} \mathrm{C} \mathrm{NMR}\right)$ using acetone- $\mathrm{d}_{6}$ or chloroform-d as the solvent. High resolution mass spectroscopy analyses were provided with a Waters series mass spectrometer (SYNAPT G1 MS model). Melting points were obtained with a Thermo scientific electrothermal digital programmable melting point apparatus system and are uncorrected. GCMS analyses were reported on an Agilent 7890A GC and 5975C MSD system equipped with Rxi-5ms capillary column (5\% diphenyl/95\% polysiloxane). Flash chromatography was applied on silica gel (230400 mesh).

\section{Synthesis of $\left[\mathrm{PdCl}_{2}(1-4)_{2}\right]$ pre-catalysts (1a-4a)}

The synthesis of monodentate phosphine based $\mathrm{Pd}$ (II) complexes is shown in Scheme 1 . The complexes $\left[\mathrm{PdCl}_{2}(\mathbf{1 - 4})_{2}\right]$ were prepared by the reaction of $\mathrm{Pd}(\operatorname{cod}) \mathrm{Cl}_{2}$ (15) with the corresponding 2-(diaryl)phosphinobenzaldehyde (1-4) in dichloromethane according to the literature $(16,17)$. To a solution of 2(diaryl)phosphinobenzaldehyde (1-4) in $\mathrm{CH}_{2} \mathrm{Cl}_{2}$ (10 mL) was added $\mathrm{Pd}$ (cod) $\mathrm{Cl}_{2}$ in $\mathrm{CH}_{2} \mathrm{Cl}_{2}(10 \mathrm{~mL})$. Reaction mixture was stirred for 2 hours at $25^{\circ} \mathrm{C}$. The solvents were then evaporated and remaining precipitate was washed with diethyl ether to give the title $\mathrm{Pd}$ (II) complexes as an orange powder.

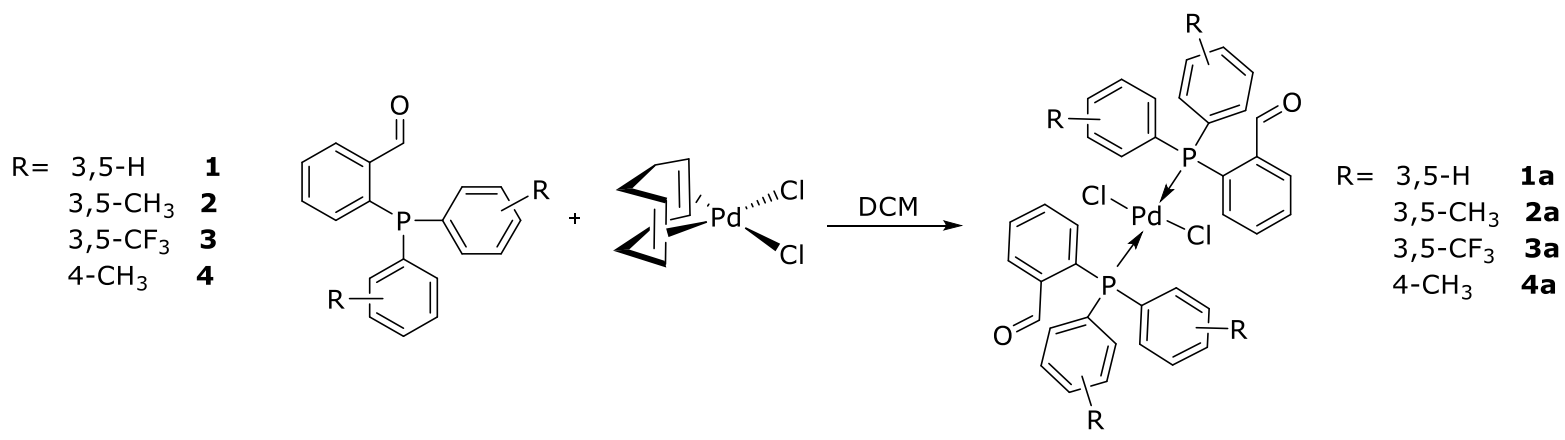

Scheme 1. Synthesis of Pd(II) Complexes.

Synthesis of $\left[\mathrm{PdCl}_{2}(\mathbf{1})_{2}\right]$, (1a). 1a was prepared using (diphenylphosphino)benzaldehyde (10.4 mmol, $3.01 \mathrm{~g})$ and $\mathrm{Pd}(\mathrm{cod}) \mathrm{Cl}_{2}(5.07 \mathrm{mmol}, 1.44 \mathrm{~g})$ 
according to the procedure given above. Yield $3.06 \mathrm{~g}(80 \%)$. Melting point: $219^{\circ} \mathrm{C} .{ }^{1} \mathbf{H}$ NMR (400.2 MHz, $\left.\mathbf{C D C l}_{3}\right)$ : $\delta$ (ppm) 10.39 (s, -C(H)O, $2 \mathrm{H}), 7.92(\mathrm{dd}, J=7.6,1.5 \mathrm{~Hz}, \mathrm{ArH}, 2 \mathrm{H}), 7.74(\mathrm{dt}$, $J=12.7,3.5 \mathrm{~Hz}, \mathrm{ArH}, 9 \mathrm{H}), 7.50(\mathrm{t}, J=7.4 \mathrm{~Hz}$, $\mathrm{ArH}, 2 \mathrm{H}), 7.38(\mathrm{~d}, J=7.1 \mathrm{~Hz}, \mathrm{ArH}, 6 \mathrm{H}), 7.33(\mathrm{~d}$, $J=7.5 \mathrm{~Hz}, \mathrm{ArH}, 7 \mathrm{H}), 6.96(\mathrm{dd}, J=12.4,5.5 \mathrm{~Hz}$, $\mathrm{ArH}, 2 \mathrm{H})$. ${ }^{31} \mathbf{P}$ NMR (162.0 $\left.\mathbf{M H z} \mathrm{CDCl}_{3}\right): \delta$ (ppm) 20.28. ${ }^{13} \mathbf{C}$ NMR (100.6 $\left.\mathbf{~ M H z , ~} \mathbf{C D C l}_{3}\right): \delta$ (ppm) $189.07(\mathrm{~s}), 134.58\left(\mathrm{t}, J_{P C}=6.4 \mathrm{~Hz}\right), 132.61$ $\left(\mathrm{t}, J_{P C}=2.5 \mathrm{~Hz}\right), 131.85\left(\mathrm{t}, J_{P C}=4.0 \mathrm{~Hz}\right), 130.28$ $\left(\mathrm{t}, J_{P C}=3.5 \mathrm{~Hz}\right), 129.82(\mathrm{~s}), 129.56(\mathrm{~s}), 128.52$ $(\mathrm{s}), 128.27$ (s), $128.02(\mathrm{~s}), 127.32\left(\mathrm{t}, J_{P C}=5.4\right.$ $\mathrm{Hz}$ ). HRMS (ESI): calcd. for $[\mathrm{M}+2 \mathrm{H}]^{2+}$ : $\mathrm{C}_{38} \mathrm{H}_{30} \mathrm{Cl}_{2} \mathrm{O}_{2} \mathrm{P} 2 \mathrm{Pd} 758.0289$; found $[\mathrm{M}+2 \mathrm{H}]^{2+}$ : 758.0131 .

\section{Synthesis of $\left[\mathrm{PdCl}_{2}(2)_{2}\right], \quad$ (2a). $2 a$ was prepared using 2-(bis(3,5-} dimethylphenyl)phosphino)benzaldehyde (2) (11.6 mmol, $4.02 \mathrm{~g})$ and $\mathrm{Pd}(\operatorname{cod}) \mathrm{Cl}_{2}(5.6 \mathrm{mmol}$, $1.61 \mathrm{~g})$ according to the procedure given above. Yield $3.83 \mathrm{~g}(78 \%)$. Melting point: $215-216^{\circ} \mathrm{C}$. ${ }^{1} \mathbf{H}$ NMR (400.2 $\mathbf{~ M H z} \mathbf{C D C l}_{3}$ ): $\delta$ (ppm) 10.51 (s, $-\mathrm{C}(\mathrm{H}) \mathrm{O}, 2 \mathrm{H}), 7.91$ (dd, J = 7.6, $1.4 \mathrm{~Hz}, \mathrm{ArH}, 2 \mathrm{H}$ ), $7.45(t, J=7.4 \mathrm{~Hz}, \mathrm{ArH}, 2 \mathrm{H}), 7.35(\mathrm{t}, J=5.7 \mathrm{~Hz}$, ArH, $10 \mathrm{H}), 7.18(\mathrm{~s}, \mathrm{ArH}, 4 \mathrm{H}), 6.92(\mathrm{dd}, J=12.6$, $5.7 \mathrm{~Hz}, \mathrm{ArH}, 2 \mathrm{H}), 2.22\left(\mathrm{~s}, \mathrm{ArCH}_{3}, 24 \mathrm{H}\right) .{ }^{31} \mathbf{P}$ NMR (162.0 $\left.\mathbf{M H z}_{1} \mathbf{C D C l}_{3}\right): \delta$ (ppm) 20.11. ${ }^{13} \mathbf{C}$ NMR (100.6 MHz, $\left.\mathbf{C D C l}_{3}\right): \delta(\mathrm{ppm}) 189.80\left(\mathrm{t}, J_{P C}=\right.$ $4.5 \mathrm{~Hz}), 138.30\left(\mathrm{t}, J_{P C}=3.3 \mathrm{~Hz}\right), 137.85\left(\mathrm{t}, J_{P C}=\right.$ $5.7 \mathrm{~Hz}), 133.52\left(\mathrm{t}, J_{P C}=2.5 \mathrm{~Hz}\right), 133.26\left(\mathrm{t}, J_{P C}=\right.$ $6.4 \mathrm{~Hz}), 132.82(\mathrm{~s}), 130.34(\mathrm{~s}), 129.87\left(\mathrm{t}, J_{P C}=\right.$ $3.3 \mathrm{~Hz}), 129.04(\mathrm{~s}), 128.80$ (s), 128.55 (s), 21.45 (s). HRMS (ESI): calcd. for $[\mathrm{M}+2 \mathrm{H}]^{2+}$ : $\mathrm{C}_{46} \mathrm{H}_{46} \mathrm{Cl}_{2} \mathrm{O}_{2} \mathrm{P} 2 \mathrm{Pd} 870.1541$; found $[\mathrm{M}+2 \mathrm{H}]^{2+}$ : 870.1385 .

$\begin{array}{llc}\text { Synthesis of } & {\left[\mathbf{P d C l}_{\mathbf{2}}(\mathbf{3})_{2}\right],} & \text { (3a). } \\ \text { prepared } & \text { 3a was } & \text { was } \\ \text { 2-(bis }(3,5-\end{array}$ bis(trifluoromethyl)phenyl)phosphino)benzaldeh yde (3) $(6.8 \mathrm{mmol}, 3.82 \mathrm{~g})$ and $\mathrm{Pd}(\mathrm{cod}) \mathrm{Cl}_{2}$ (3.3 mmol, $0.94 \mathrm{~g}$ ) according to the procedure given above. Yield $3.62 \mathrm{~g}(84 \%)$. Melting point: $225^{\circ} \mathrm{C}$. ${ }^{1} \mathrm{H}$ NMR (400.2 $\left.\mathrm{MHz},\left(\mathrm{CD}_{3}\right)_{2} \mathbf{C O}\right): \delta$ (ppm) $9.87(\mathrm{~s},-\mathrm{C}(\mathrm{H}) \mathrm{O}, 2 \mathrm{H}), 8.32(\mathrm{t}, \mathrm{J}=4.7 \mathrm{~Hz}$, $\mathrm{ArH}, 8 \mathrm{H}), 8.17(\mathrm{~d}, \mathrm{~J}=1.5 \mathrm{~Hz}, \mathrm{ArH}, 2 \mathrm{H}), 8.14(\mathrm{~s}$, $\mathrm{ArH}, 4 \mathrm{H}), 7.78(\mathrm{t}, \mathrm{J}=7.5 \mathrm{~Hz}, \mathrm{ArH}, 2 \mathrm{H}), 7.63$ (td, $J=7.6,0.9 \mathrm{~Hz}, \mathrm{ArH}, 2 \mathrm{H}), 7.29$ (dd, $J=13.1,5.7$ $\mathrm{Hz}, \mathrm{ArH}, 2 \mathrm{H}) .{ }^{31} \mathbf{P}$ NMR (162.0 $\left.\mathbf{M H z} \mathbf{C D C l}_{3}\right): \delta$ (ppm) 22.72. ${ }^{13} \mathbf{C}$ NMR (100.6 $\left.\mathbf{~ M H z , ~}\left(\mathbf{C D}_{\mathbf{3}}\right)_{\mathbf{2}} \mathbf{C O}\right)$ : $\delta(\mathrm{ppm}) 192.95(\mathrm{~s}), 140.18\left(\mathrm{t}, J_{P C}=4.1 \mathrm{~Hz}\right)$, $136.36\left(\mathrm{~d}, J_{P C}=3.5 \mathrm{~Hz}\right), 136.01\left(\mathrm{t}, J_{P C}=4.1 \mathrm{~Hz}\right)$, $135.45\left(\mathrm{t}, J_{P C}=2.0 \mathrm{~Hz}\right), 135.00\left(\mathrm{t}, J_{P C}=4.4 \mathrm{~Hz}\right)$, $133.88(\mathrm{~s}), 133.64(\mathrm{~s}), 133.39(\mathrm{~s}), 132.28(\mathrm{t}$, $\left.J_{P C}=5.2 \mathrm{~Hz}\right), 131.95\left(\mathrm{t}, J_{P C}=5.2 \mathrm{~Hz}\right), 127.63(\mathrm{t}$, $\left.J_{P C}=23.2 \mathrm{~Hz}\right), 126.01(\mathrm{~s}), 124.03\left(\mathrm{q}, J_{P C}=272.5\right.$ $\mathrm{Hz}$ ). HRMS (ESI): calcd. for $[\mathrm{M}+2 \mathrm{H}]^{2+}$ : $\mathrm{C}_{46} \mathrm{H}_{22} \mathrm{Cl}_{2} \mathrm{~F}_{24} \mathrm{O}_{2} \mathrm{P}_{2} \mathrm{Pd} 1301.9280$; found $[\mathrm{M}+2 \mathrm{H}]^{2+}$ : 1301.9125 .

Synthesis of $\left[\mathrm{PdCl}_{2}(4)_{2}\right], \quad(4 a) .4 a$ was prepared using 2-(bis(4tolyl)phosphino)benzaldehyde (4) (9.54 mmol, $3.03 \mathrm{~g})$ and $\mathrm{Pd}(\mathrm{cod}) \mathrm{Cl}_{2}(4.6 \mathrm{mmol}, 1.32 \mathrm{~g})$ according to the procedure given above. Yield
$3.09 \mathrm{~g}(82 \%)$. Melting point: $226^{\circ} \mathrm{C} .{ }^{\mathbf{1}} \mathbf{H}$ NMR (400.2 MHz, CDCl 3$)$ : $\delta(\mathrm{ppm}) 10.58(\mathrm{~s},-\mathrm{C}(\mathrm{H}) \mathrm{O}$, $2 \mathrm{H}), 8.02$ (dd, $J=7.6,1.4 \mathrm{~Hz}, \mathrm{ArH}, 2 \mathrm{H}), 7.73(\mathrm{dt}$, $J=7.6,5.6 \mathrm{~Hz}, \mathrm{ArH}, 8 \mathrm{H}), 7.57(\mathrm{t}, J=7.5 \mathrm{~Hz}$, $\mathrm{ArH}, 2 \mathrm{H}), 7.45(\mathrm{t}, J=7.5 \mathrm{~Hz}, \mathrm{ArH}, 2 \mathrm{H}), 7.23(\mathrm{~d}$, $\mathrm{J}=7.9 \mathrm{~Hz}, \mathrm{ArH}, 8 \mathrm{H}), 7.06(\mathrm{dd}, \mathrm{J}=12.9,5.6 \mathrm{~Hz}$, $\mathrm{ArH}, 2 \mathrm{H}), 2.40$ (s, $\left.\mathrm{ArCH}_{3}, 12 \mathrm{H}\right) .{ }^{31} \mathbf{P}$ NMR (162.0 $\left.\mathbf{M H z}_{1} \mathbf{C D C l}_{3}\right): \delta(\mathrm{ppm}) 18.92 .{ }^{13} \mathbf{C}$ NMR (100.6 $\left.\mathbf{M H z}, \mathbf{C D C l}_{3}\right): \delta(\mathrm{ppm}) 190.08\left(\mathrm{t}, J_{P C}=4.2 \mathrm{~Hz}\right)$, $141.20(\mathrm{~s}), 138.29\left(\mathrm{t}, J_{P C}=3.6 \mathrm{~Hz}\right), 135.54(\mathrm{t}$, $\left.J_{P C}=6.6 \mathrm{~Hz}\right), 133.47\left(\mathrm{t}, J_{P C}=2.4 \mathrm{~Hz}\right), 133.20(\mathrm{~s})$, $133.00(\mathrm{~s}), 132.76\left(\mathrm{t}, J_{P C}=3.9 \mathrm{~Hz}\right), 130.59(\mathrm{t}$, $\left.J_{P C}=3.6 \mathrm{~Hz}\right), 130.40(\mathrm{~s}), 129.19\left(\mathrm{t}, J_{P C}=5.5 \mathrm{~Hz}\right)$, 126.14 (s), 125.89 (s), 125.63 (s), 21.49 (s). HRMS (ESI): calcd. for $[\mathrm{M}+2 \mathrm{H}]^{2+}$ : $\mathrm{C}_{42} \mathrm{H}_{38} \mathrm{Cl}_{2} \mathrm{O}_{2} \mathrm{P}_{2} \mathrm{Pd} 814.0915$; found $[\mathrm{M}+2 \mathrm{H}]^{2+}$ : 814.0758 .

\section{Procedure for the SM coupling reaction}

Aryl halide $(1.0 \mathrm{mmol})$, phenylboronic acid (1.2 $\mathrm{mmol})$, base $(1.2 \mathrm{mmol})$, catalyst $(0.01 \mathrm{mmol})$ and $4.0 \mathrm{~mL}$ of solvent (organic solvent/water:2.0 $\mathrm{mL} / 2.0 \mathrm{~mL}$ ) was added in a sealed tube and the mixture was stirred for 5 hours at room temperature. Next, the mixture was washed with saturated ammonium chloride solution and extracted with chloroform. The organic phase was dried and then chromatographed on silica gel. Conversions and yields were determined by GCMS analyses.

\section{RESULTS AND DISCUSSION}

\section{Characterization}

All the palladium(II) complexes $\mathbf{1 a - 4 a}$ are airand moisture-stable and they are soluble in a wide range of polar solvents such as $\mathrm{CHCl}_{3}, \mathrm{MeOH}$ and DCM, but insoluble in low-polar solvents or non-polar solvents. The NMR $\left({ }^{1} \mathrm{H},{ }^{13} \mathrm{C}\right.$ and $\left.{ }^{31} \mathrm{P}\right)$ spectra of the complexes were carried out in order to contribute to the characterization of the synthesized compounds. The $\mathrm{Pd}(\mathrm{II})$ complexes were further characterized by high resolution mass spectroscopy (HRMS) analyses and the results are in agreement with the proposed structures. Based on ${ }^{31} \mathrm{P}$ NMR analysis, displacement of the phosphorus singlet peaks from up field in non-coordinated ligands (1: $11.96 ; 2:-12.51 ; 3:-6.49 ; 4:-13.71 \mathrm{ppm})$ to the down field in the $\mathrm{Pd}(\mathrm{II})$ complexes (1a: 20.28; 2a: 20.11; 3a: 22.72; 4a: 18.92 ppm) suggest the coordination of desired $\mathrm{Pd}(\mathrm{II})$ complexes $(9,16,17)$. Also, the appearance of only one singlet indicates the formation of only one product. Meanwhile, the disappearance of the characteristic doublet (due to the coupling with the lone pair of phosphorus atom) of the aldehyde proton in the free ligands (1: $9.04 \mathrm{ppm}\left(J_{P H}=5.1\right.$ $\mathrm{Hz}) ; 2: 8.94 \mathrm{ppm}\left(\mathrm{J}_{P H}=5.3 \mathrm{~Hz}\right) ; 3: 8.57 \mathrm{ppm}$ $\left.\left(J_{P H}=3.2 \mathrm{~Hz}\right) ; 4: 10.58 \mathrm{ppm}\left(J_{P H}=5.5 \mathrm{~Hz}\right)\right)$ and formation of a singlet for the $\mathrm{Pd}(\mathrm{II})$ complexes (1a: 10.39; 2a: 10.51; 3a: 9.87; 4a: 10.58 ppm) further confirmed the formation of the desired monodentate complexes (16-20). Otherwise, the signal of the methyl protons in $\mathbf{2 a}$ and $\mathbf{4 a}$ appeared at 2.22 and 2.40 ppm as singlet, 
respectively. The signals for the aromatic protons of the complexes appear in the region 6.96-8.48 ppm as expected. In the ${ }^{13} \mathrm{C}$ NMR spectrum of the complexes, the signals of the aldehyde carbon are found at 189.07 (1a), 189.80 (2a), 192.95 (3a) and 190,08 (4a) ppm as singlet and triplet (probably carbon-carbon interaction has become more active due to the increasing electron density of the methyl carbon by methyl protons), respectively. Besides that, the signals of the methyl carbon, for the $\mathbf{2} \mathbf{a}$ and $\mathbf{4 a}$ complexes, were observed at 21.45 and $21.49 \mathrm{ppm}$, respectively $(19,21)$. Also, ${ }^{13} \mathrm{C}$ NMR spectrum of the complex $\mathbf{3 a}$ showed the characteristic signal of $-\mathrm{CF}_{3}$ bonded-carbon $\left(\mathrm{CF}_{3}-\mathrm{Ar} \underline{\mathrm{C}}\right.$ ) as a quartet at $124.03 \mathrm{ppm}\left(J_{F C}=272.5 \mathrm{~Hz}\right)$ due to the fluorinecarbon coupling (13). These results and high resolution mass spectroscopy data which showed $[\mathrm{M}+2 \mathrm{H}]^{2+}$ as the highest molecular weight fragment together support and are in agreement for our suggested structures of the monodentate phosphine-palladium(II) pre-catalysts shown in Scheme 1 (see supporting information).

\section{SM coupling reactions}

Initially, we performed optimization studies using various bases $\left(\mathrm{K}_{2} \mathrm{CO}_{3}, \mathrm{NaOAC}, \mathrm{NaOH}\right.$, and $\left.\mathrm{Et}_{3} \mathrm{~N}\right)$ and polar aprotic solvents (1,4-dioxane and DMF) to determine how solvents and bases affect the SM coupling reaction between phenylboronic acid and bromobenzene in the presence of catalyst $\mathbf{1 a}$ (substrate/catalyst:100/1) at room temperature (Figure 1). Among the bases examined, $\mathrm{Et}_{3} \mathrm{~N}$ afforded none or very little of the biphenyl in both DMF and 1,4-dioxane. We found better conversion for $\mathrm{K}_{2} \mathrm{CO}_{3}$ in both solvent when compared to the $\mathrm{Na}_{2} \mathrm{CO}_{3}$, it appears that the cation plays a key role and this is known as "potassium effect" which has been previously reported (22-24). Otherwise, when $\mathrm{NaOH}$ was used as the base, good to excellent yields (73\% and $98 \%$ for 1,4 -dioxane and DMF, respectively) were obtained for this catalytic system. These results showed strong base has a great effect to neutralize acidic condition and to generate the active species in the catalytic system for facilities the transmetallation step compared to the weak bases such as $\mathrm{K}_{2} \mathrm{CO}_{3}, \mathrm{Na}_{2} \mathrm{CO}_{3}$ and $\mathrm{Et}_{3} \mathrm{~N}$ in $\mathrm{SM}$ coupling reaction (25). On the other hand, in all cases, DMF gave better coupling product when comparing the results obtained from 1,4-dioxane. It's known polar aprotic solvents are generally preferred for the SM coupling reactions since they allow the higher solubility of the catalyst and substrates used $(26,27)$. It can also be said DMF is more likely to coordinate to the $\mathrm{Pd}(\mathrm{II})$ center since the nitrogen donor in DMF is a softer base than oxygen donor in 1,4-dioxane (6).

It's noted that reaction temperature also plays an important role for the SM coupling reaction. We did not investigate the higher reaction temperatures since we achieved almost complete conversion with a combination of DMF-KOH solvent-base system in the preliminary experiment here reported. Nevertheless, it clearly appears from the optimization studies that the best catalytic activity was obtained in DMF in the presence of $\mathrm{NaOH}$ at room temperature.

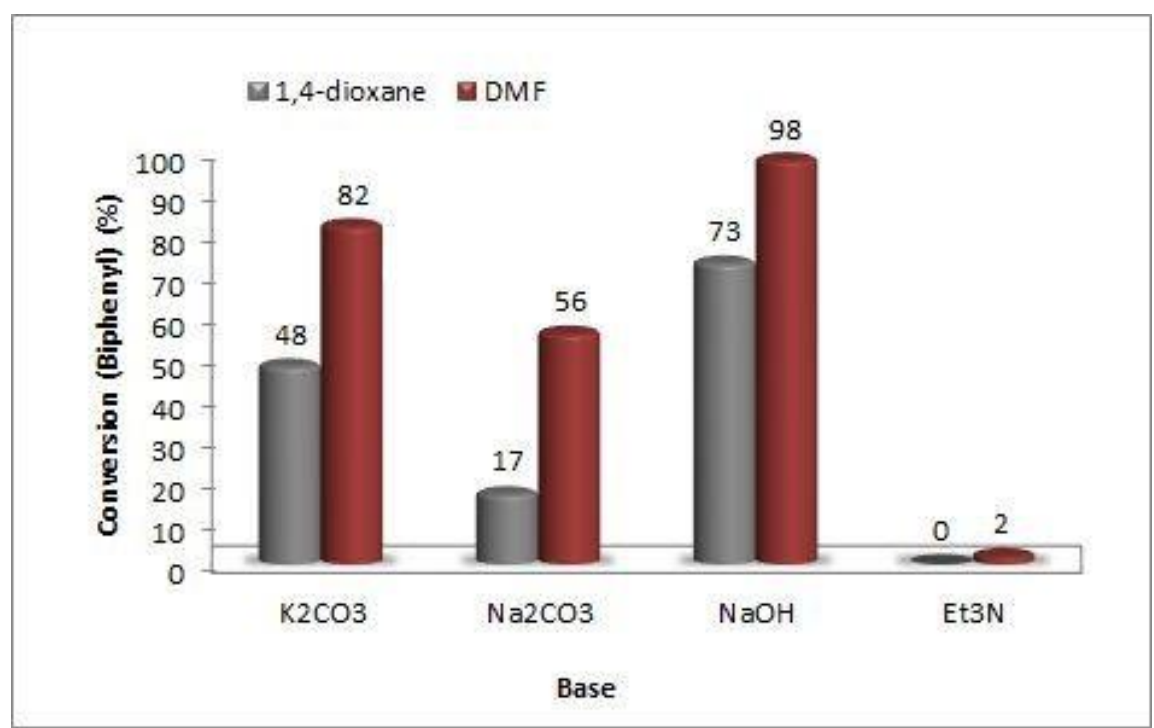

Figure 1: The effect of base and solvent on SM coupling reaction between bromobenzene and phenylboronic acid. Reaction conditions: $\mathrm{PhBr}(1.0 \mathrm{mmol}), \mathrm{PhB}(\mathrm{OH})_{2}(1.2 \mathrm{mmol})$, base $(1.2$ $\mathrm{mmol})$, cat. (1a) $(0.01 \mathrm{mmol})$, solvent $(2 \mathrm{~mL}), \mathrm{H}_{2} \mathrm{O}(2 \mathrm{~mL})$, temperature: $25^{\circ} \mathrm{C}$, time: $5 \mathrm{~h}$. Yields were analyzed by GC-MS.

After the optimization of the reaction conditions, we examined a range of substituted aryl bromides in the SM coupling reaction with phenylboronic acid. The results were given in Table 1 . We have discovered that, for activated, sterically hindered, and deactivated aryl bromides, our catalyst systems can serve as an effective catalyst. For example, the reaction of 1-bromo-4-nitrobenzene containing electron-withdrawing group at para position, which could accelerate the rate determining oxidative addition step in the catalytic cycle due to the reduced electron density 
of $\mathrm{C}-\mathrm{Br}$ bond, gave 4-nitrobiphenyl as the principal product in excellent yields (87-99\%) with all catalysts (entry 21-24) $(6,28)$. Our catalysts are also effective towards the coupling of 2-bromoanisole, 2-bromotoluene and 2bromoacetophenone, which have bulky methoxy, -ethyl and -aceto group at ortho position respectively, giving corresponding biaryls as major product up to $68 \%$ conversion (entry 1 $4,13-16$, and 25-28) and steric effect of these substituents on the $\mathrm{C}-\mathrm{Br}$ bond were well tolerated. In general, the reaction rate slows down in the presence of the electronically deactivated aryl halides, which have electronreleasing groups such as -methoxy and -methyl group on the phenyl ring for the SM coupling reactions $(14,29)$. However, the coupling of these deactivated aryl bromides with phenylboronic acid gave desired coupling product moderate to good yields by all catalysts. Also, the catalytic efficiency of the palladium(II) precatalysts 1a-3a were investigated for the coupling of 2-bromo-6-methoxynaphthalene with phenylboronic acid and moderate coupling product was obtained (58-70\%, entries 9-12). These results showed that our monodentate phosphine based $\mathrm{Pd}$ (II) complexes were capable of effectively catalyzing the coupling of bromobenzene and phenylboronic acid at room temperature.

Table 1. SM coupling reactions with monodentate phosphine based Pd(II) pre-catalysts (1a$4 a)^{a}$

\begin{tabular}{|c|c|c|c|c|c|c|}
\hline Entry & $\begin{array}{c}\text { Aryl } \\
\text { bromide } \\
\end{array}$ & Product & Catalyst & $\begin{array}{c}\text { Conversion } \\
(\%)^{\mathrm{b}}\end{array}$ & $\begin{array}{l}\text { Yield } \\
(\%)^{b} \\
\end{array}$ & $\begin{array}{c}\text { TOF } \\
\left(\mathbf{h}^{-1}\right)^{\mathrm{c}}\end{array}$ \\
\hline 1 & & & $1 a$ & 53 & 49 & 11 \\
\hline 2 & & & $2 a$ & 51 & 48 & 10 \\
\hline 3 & & & $3 a$ & 37 & 31 & 7 \\
\hline 4 & & & $4 a$ & 48 & 43 & 10 \\
\hline 5 & & & $1 a$ & 68 & 65 & 14 \\
\hline 6 & & & $2 a$ & 80 & 77 & 16 \\
\hline 7 & & & $3 a$ & 84 & 80 & 17 \\
\hline 8 & $\mathrm{Br}$ & & $4 a$ & 65 & 60 & 13 \\
\hline 9 & & & $1 a$ & 58 & 55 & 12 \\
\hline 10 & & & $2 a$ & 63 & 58 & 13 \\
\hline 11 & & & $3 a$ & 76 & 75 & 15 \\
\hline 12 & $\mathrm{Br}$ & & $4 a$ & 70 & 61 & 14 \\
\hline 13 & & & $1 a$ & 45 & 43 & 9 \\
\hline 14 & & & $2 a$ & 61 & 58 & 12 \\
\hline 15 & & & $3 a$ & 68 & 65 & 14 \\
\hline 16 & & & $4 a$ & 56 & 55 & 11 \\
\hline 17 & & & $1 a$ & 64 & 56 & 13 \\
\hline 18 & & & $2 a$ & 70 & 64 & 14 \\
\hline 19 & & & $3 a$ & 83 & 78 & 17 \\
\hline 20 & $\mathrm{Br}$ & & $4 a$ & 67 & 65 & 13 \\
\hline 21 & & & $1 a$ & 99 & 96 & 20 \\
\hline 22 & & & $2 a$ & 99 & 97 & 20 \\
\hline 23 & & & $3 a$ & 99 & 87 & 20 \\
\hline 24 & $\mathrm{Br}$ & & $4 a$ & 87 & 85 & 17 \\
\hline 25 & & & $1 a$ & 40 & 38 & 8 \\
\hline 26 & & & $2 a$ & 39 & 37 & 8 \\
\hline 27 & & & $3 a$ & 55 & 53 & 11 \\
\hline 28 & $\mathrm{Br}$ & & $4 a$ & 40 & 37 & 8 \\
\hline
\end{tabular}

aConditions: Aryl bromide $(1.0 \mathrm{mmol}), \mathrm{PhB}(\mathrm{OH})_{2}(1.2 \mathrm{mmol}), \mathrm{KOH}(1.2 \mathrm{mmol})$, cat. $(0.01$ $\mathrm{mmol}), \operatorname{DMF}(5 \mathrm{~mL}), 25^{\circ} \mathrm{C}$, time: $5 \mathrm{~h}$.

${ }^{b}$ Conversions and yields were analyzed by GCMS.

'Turnover frequency $=($ mole of product $/$ mole of catalyst $) /$ time $(h)$.

\section{CONCLUSION}

We have synthesized and fully characterized a series of monodentate triaryl phosphine based 
Pd(II) complexes. These complexes are insensitive to oxygen and moisture. Catalytic activity of these pre-catalysts were tested for SM coupling reaction between phenylboronic acid and bromobenzene and an extensive study on the scope of these complexes was performed. The results showed that, moderate to excellent yields were obtained for these pre-catalysts at room temperature and sterically hindered and deactivated aryl bromides were well tolerated.

\section{ACKNOWLEDGMENTS}

We are grateful to the Mersin University for supporting this research.

\section{REFERENCES}

1. Dounay AB, Overman LE. The Asymmetric Intramolecular Heck Reaction in Natural Product Total Synthesis. Chem. Rev. 2003; 103:2945-63.

2. Tsuji J. Palladium Reagents and Catalysts; Wiley: New York, 2004; Chapter 3:105.

3. Yin L, Liebscher J. Carbon-Carbon Coupling Reactions Catalyzed by Heterogeneous Palladium Catalysts. Chem. Rev. 2007; 107:13373.

4. Polshettiwar V, Decottignies A, Len C, Fihri A. Suzuki-Miyaura Cross-Coupling Reactions in Aqueous Media: Green and Sustainable Syntheses of Biaryls. ChemSusChem. 2010; 3:502-22.

5. Suzuki A. Cross-Coupling Reactions of Organoboranes: An Easy Way To Construct C-C Bonds (Nobel Lecture). Angew. Chem. Int. Ed. 2011; 50:6723-37.

6. Mahamo T, Mogorosi MM, Moss JR, Mapolie SF, Slootweg JC, Lammertsma K, and Smith GS. Neutral palladium(II) complexes with $\mathrm{P}, \mathrm{N}$ Schiff-base ligands: Synthesis, characterization and application as Suzuki Miyaura coupling catalysts. J. Organomet. Chem. 2012; 703:34-42. 7hao $F$, Xin $L$, Zhang $Y$, Jia $X$.
Monosphorus-coordinated palladium(II) complexes as new catalyst for Mizoroki-Heck reaction of aryl halides with electron-deficient olefins. Chinese Chemical Letters. 2018; 29; 493-96.

8. Sabouncheia SJ, Hosseinzadeha $M$, Jevinani MZ. Monodentate palladium(0)[60]fullerene complexes of diphosphine ligands as efficient and sustainable nanocatalysts for Mizoroki-Heck coupling reaction of aryl chlorides. New J. Chem. 2017; 41: 9701-09

9. Huang $P$, Hong FE. Amination and Suzuki coupling reactions catalyzed by palladium complexes coordinated by cobalt-containing monodentate phosphine ligands with bistrifluoromethyl substituents on bridged arylethynyl: Observation of some unusual metalcontaining compounds. J. of Org. Chem. 2009; 694:113-21.

10. Armarego WLE, and Chai CLL. Purification of Laboratory Chemicals; Oxford: Pergamon Press. 2003; Chapter 5.

11. Laue S, Greiner L, Wöltinger J, Liese A. Continuous Application of Chemzymes in a Membrane Reactor: Asymmetric Transfer Hydrogenation of Acetophenone. Adv. Synt. Catal. 2001; 343: 711-20.

12. Ros A, Estepa B, Bermejo A, Álvarez E, Fernández R, Lassaletta JM. Phosphino hydrazones as suitable ligands in the asymmetric Suzuki-Miyaura cross-coupling. J Org Chem. 2012; 77(10): 4740-50.

13. Yilmaz MK. Palladium(II) complexes with new bidentate phosphine-imine ligands for the Suzuki C-C coupling reactions in supercritical carbon dioxide. J. of Supercritical Fluids. 2018; 138: 221-27.

14. Yılmaz MK, Güzel B. Iminophosphine palladium(II) complexes: synthesis, characterization, and application in Heck crosscoupling reaction of aryl bromides. Appl. Organometal. Chem. 2014; 28:529-36.

15. Drew D, Doyle JR, and Shaver AG. Cyclic Diolefin Complexes of Platinum and Palladium. Inorganic Syntheses. 2007; 28:348-49.

16. Mahalakshmi $\mathrm{H}$, Phadnis PP, Jain VK, Tiekinkh ERT. Synthesis, spectroscopy and structures. 2004;43(November):2287-93.

17. Watkins SE, Craig DC, Colbran SB. A palladium(II) complex of a new iminophosphine ligand derived from diethylenetriamine and 2(diphenylphosphino)benzaldehyde. 2000; 307: 134-38.

18. Hong FE, Ho YJ, Chang YC, Huang YL. Synthesis of cobalt-containing monodentate phosphine ligand and application toward Suzuki cross-coupling reactions. J. of Org. Chem. 2005; 690:1249-57.

19. Dodds DL, Boele MDK, Strijdonck GPF, Vries JG, Leeuwen PWNM, and Kamer PCJ. Design, Testing and Kinetic Analysis of Bulky Monodentate Phosphorus Ligands in the MizorokiHeck Reaction. Eur. J. Inorg. Chem. 2012; 166071.

20. Yılmaz MK, Keleş M. The catalytic activity of Palladium(II) complexes containing PN ligands in the Heck and Suzuki C-C coupling reactions. JOTCSA. $2018 ; 5(1): 133-48$. 
21. Cheng $\mathrm{YH}$, Weng CM, Hong FE. Preparation of monodentate phosphinite ligands: their applications in palladium catalyzed Suzuki reactions. Tetrahedron. 2007; 63:12277-85.

22. Bedford RB, Hazelwood SL, Horton PN, Hursthouse MB. Orthopalladated phosphinite complexes as high-activity catalystsfor the Suzuki reaction. Dalton Trans. 2003; 4164-4174.

23. Bedford RB, Hazelwood SL, Limmert ME, Albisson DA, Draper SM, Scully PN, Coles SJ, Hursthouse MB. Orthopalladated and -platinated Bulky Triarylphosphite Complexes: Synthesis, Reactivity and Application as High-Activity Catalysts for Suzuki and Stille Coupling Reactions. Chem. Eur. J. 2003; 9:3216-27.

24. So CM, Yeung CC, Lau CP, Kwong FYJ. A New Family of Tunable Indolylphosphine Ligands by One-Pot Assembly and Their Applications in Suzuki-Miyaura Coupling of Aryl Chlorides. Org. Chem. 2008; 73:7803-06.

25. Mondal M, Begum T, Gogoi PK, Bora U. Gallic Acid Derived Palladium(0) Nanoparticles: An In Situ Formed "Green and Recyclable" Catalyst for Suzuki-Miyaura Coupling in Water. Chemistry Select. 2016; 1: 4645-51.
26. Billingsley K, Buchwald SL. Highly Efficient Monophosphine-Based Catalyst for the Palladium-Catalyzed Suzuki-Miyaura Reaction of Heteroaryl Halides and Heteroaryl Boronic Acids and Esters. J. Am. Chem. Soc. 2007; 129: 335866.

27. Zapf A, Beller M. Palladium Catalyst Systems for Cross-Coupling Reactions of Aryl Chlorides and Olefins. Chem. Eur. J. 2001; 7: 2908-15.

28. Nobre SM, Monteiro AL. Pd complexes of iminophosphine ligands: A homogeneous molecular catalyst for Suzuki-Miyaura crosscoupling reactions under mild conditions. J. Mol. Cat. A: Chem. 2009; 313:65-73.

29. Scrivanti A, Bertoldini M, Matteoli U, Beghetto V, Antonaroli S, Marini A, Crociani B. Highly efficient Heck olefin arylation in the presence of iminophosphine-palladium(0) complexes. Journal of Molecular Catalysis A: Chemical. 2005; 235:12-16. 
